\title{
Structural and functional peculiarities of plasminogen activator inhibitor PAI-1
}

\author{
D. D. Zhernossekov, E. N. Zolotareva, A. S. Kondratuk
}

Palladin Institute of Biochemistry, National Academy of Science of Ukraine

9, LeontovichaStr., Kyiv, Ukraine, 01601

chemikdd@mail.ru

\begin{abstract}
PAI-1, an important component of the hemostasis system, is a specific inhibitor of both urokinase type and tissue type plasminogen activators. PAI-1 belongs to the serpin family. The interaction between somatomedin-like domain of vitronectin and PAI-1 leads to stabilization of the latter. PAI-1 latency transition is related to the conformational changes in the reactive central loop. The inhibitory mechanism of PAI-1 is in accordance with the classic scheme of serpin action. PAI-1 blocks the adhesion mediated by UPA and integrins, so this inhibitor plays an important role in adhesion process and angiogenesis. An altered PAI-1level is associated with the development of cardiovascular diseases, kidney fibrosis, diabetis, cancerogenesis.
\end{abstract}

Keywords: PAI-1, fibrinolysis, cell migration.

PAI-1 belongs to the serpin family (serine proteinase inhibitors) and is a natural specific inhibitor of both tissue plasminogen activator (TPA) and urokinase one (UPA). Among the components of hemostasis PAI-1 plays a very important role due to its unique structural and functional peculiarities. In the last decade the convinced proofs were obtained concerning the participation of this protein not only in fibrinolysis but also in cell adhesion modulation. The elevation of PAI-1 level in plasma is observed at tumor growth and under other pathological states in human organism. The PAI-1 deficiency in plasma can lead to bleeding while the PAI-1 level elevation is related with the risk of cardiovascular diseases such as myocardium infarction, arteriosclerosis, deep vein thrombosis [1,2]. During kidney disease the level of PAI-1 in this tissue

\footnotetext{
(C) Institute of Molecular Biology and Genetics NAS of Ukraine, 2010
}

is considerably increased which can lead to fibrotic complications [3]. During adiposis the inhibitor biosynthesis takes place in adipocytes immediately [4, 5]. PAI-1 may be of significance at chronic inflammatory processes in lung tissue [6]. Some authors, considering the role of PAI-1 in pathological processes, noticed that high level of PAI-1 is unfavorable index in cancer and cardiovascular diseases [1,3-8].

Besides PAI-1 in human organism there are two other plasminogen activator inhibitors known as PAI-2 and PAI-3 [9-11]. They differ from PAI-1 by their molecular masses, content in plasma and are less specific towards plasminogen activators (see table 1). It was established, that PAI-3 has a specific function as an inhibitor of activated protein $\mathrm{C}$ which is one of the main components of anticoagulant system. A biological function of PAI-2 has not been defined yet. 
Characteristics of PAI proteins

\begin{tabular}{|c|c|c|c|c|}
\hline Name & Concentration in human plasma & Molecular mass, $\mathrm{KDa}$ & \multicolumn{2}{|c|}{ The constant inhibition $\left(\mathrm{M}^{-1} \mathrm{c}^{-1}\right)$ toward } \\
\hline PAI-1 & In average $24 \mathrm{ng} / \mathrm{ml}$ & 52 & $10^{6}$ & $10^{7}$ \\
\hline PAI-2 & $\begin{array}{l}\text { Negligible under normal state. } \\
\text { At pregnancy } 100-300 \mathrm{ng} / \mathrm{ml}\end{array}$ & 60 & $9 \cdot 10^{5}$ & $2 \cdot 10^{5}$ \\
\hline
\end{tabular}

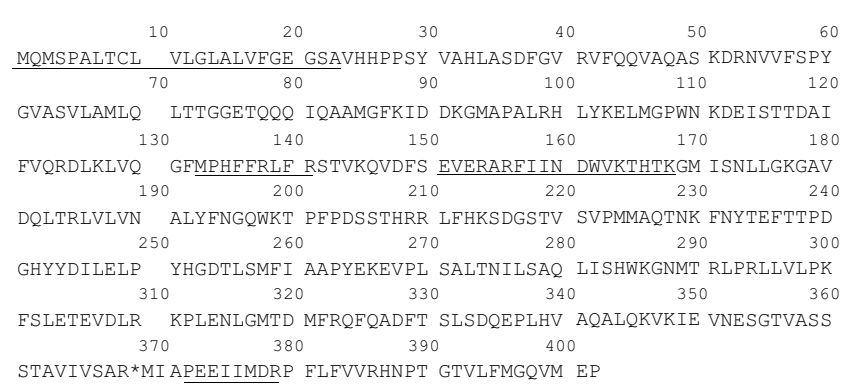

Fig. 1. Primary structure of human PAI-1 (All numbers of amino acid residues correspond to the protein premature form). N-glycosylated Asn [25]; MQMSPALTCLVLGLALVFGEGSA or MQMSPALTCLVLGLALVFGEG is a signal peptide [23, 24]; FRLFFRLFR and EVERARFIINDWVKTHTK are sites of vitronectin binding $[35,36] ; \mathrm{R} * \mathrm{M}$ is a peptide bond, which is cleaved by TPA or UPA; PEEIIMDR is a site of TPA or UPA binding.

Among these proteins PAI-1 is the most interesting, because this inhibitor has structural peculiarities, which help it to interact with the components of extracellular matrix and therefore its functional role is more complicated $[12,13]$.

The average concentration of PAI-1 in human plasma is $24 \mathrm{ng} / \mathrm{ml}$, but it can fluctuate from 6 to 85 $\mathrm{ng} / \mathrm{ml}$. The PAI- 1 concentration is $2-3$ times more in arterial blood than in venous one $[14,15]$. Besides, the concentration of this inhibitor is changing during the day: it is higher before noon than in the afternoon [11]. According to a modern version, the pool of PAI-1 is formed from several sources: platelets, hepatocytes, endothelial cells, macrophages, and adipocytes [16]. Platelets contain approximately $90 \%$ of PAI-1.

Structural peculiarities of PAI-1. The gene of human PAI-1 is localized on chromosome 7 in the region q 21.3-q 22 [17]. It contains 9 exons and 8 introns. Higher primates have two different transcripts of PAI-1 m-RNA: 2.6 and $3.6 \mathrm{~kb}$. However, the translation products are the proteins of the same size
[18]. The transcription and translation of platelet PAI-1 occur in megakariocytes. However, megakaryocytes contain a considerable amount of PAI-1 m-RNA, which biosynthesis goes on at the platelet stage [19]. The PAI-1 gene transcription is regulated by a large number of hormones, cytokines, and growth factors $[16,20,21]$. The induction of PAI-1 expression by glucocorticoid hormones is of special interest, as PAI-1 was discovered as a dexamethasone-induced fibrinolytic inhibitor [22].

PAI-1 is synthesized as a precursor containing 402 amino acid residues (Fig. 1). During protein globule formation the signal peptide of 21 or 23 residues is cleaved from the molecule. So, the mature protein contains 379 or 381 amino acid residues [23, 24]. PAI-1 has 3 potential glycosylation sites at Asn 232, Asn288, and Asn 352 [25]. The glycosylation PAI-1 depends on its origin in human organism.

It was shown that PAI-1, purified from plasma or platelets of healthy donors, had no glycans, meanwhile PAI-1 from endothelial cells or adipose tissue was glycosylated. It led to the conclusion, that the main source of PAI-1in plasma of healthy people could be platelets but not endothelial cells [26]. The recent investigations have shown the importance of glycosylation for the functional activity of PAI-1. The glycosylated form of PAI-1 was found to possess a higher inhibitor activity [27].

Interaction of PAI-1 with vitronectin. The binding of vitronectin is very important for PAI-1 functioning $[13,28]$. Vitronectin is found in plasma in a concentration of $2-4 \mu \mathrm{M}$, mainly in a monomeric conformation, however, it has multimeric form in extracellular matrix [29]. PAI-1 is present in $\alpha$-granules of platelets as a complex with vitronectin [30-32]. Using the methods of electron microscopy [33] and FITC-labeled proteins in flow cytometry [34] 
it was shown that after platelets activation and releasing from $\alpha$-granules the above-mentioned complex stays on the surface of activated platelets. The sites of vitronectin binding to PAI-1 were determined [35, 36] (see Fig.1). The method of site-directed mutagenesis showed that the most important residues in PAI-1 structure, which provide interaction with vitronectin, were Phe 132, Met 133, Leu 139 and Gly 146 [37].

On the other hand, the somatomedin-like domain (SMB) of vitronectin, containing 44 amino acid residues, is in charge of PAI-1 binding [34]. It is followed by the RGD sequence, which is known as an integrin-binding site. It was shown that vitronectin can bind C-terminal part of vimentin, which is exposed on the membrane of activated platelets [34].

During the experiments with immobilized proteins it was established that $\mathrm{Kd}$ value for binding immobilized vitronectin to PAI-1 was $1.9 \times 10^{-7}$, however, if PAI-1 was immobilized, its $\mathrm{Kd}$ value for vitronectin binding was $5.5 \times 10^{-8}$. So, it was made a conclusion, that in vitronectin molecule there are at least two sites of PAI-1 binding, and one of these sites, which has higher affinity, becomes unapproachable after immobilization [38, 39]. The site of PAI-1 binding on the vitronectin molecule is different from integrin-binding site RGD. However, PAI-1 binding in the region of SMB domain can inhibit cell adhesion induced by integrins, possibly due to physical barrier [40, 41].

PAI-1 latency transition. PAI-1 can be found in active $S$ (stressed) or latent R (relaxed) state [42]. It is known, that this protein is synthesized in an active configuration but spontaneously can convert to thermodynamically more stable latent form [43]. Reported half-life of the active PAI-1 is approximately 1-2 hours at $37^{\circ} \mathrm{C}$ and $\mathrm{pH}$ 7.4. However, this time can be decreased under conditions of low temperature and $\mathrm{pH}[44,45]$. In plasma the active PAI-1 is stabilized by its binding with vitronectin. The $\mathrm{Kd}$ value for binding of vitronectin to the active PAI- 1 is $80 \mathrm{nM}$, while the latent PAI-1 binds with at least 200-fold lower affinity [46]. PAI-1 can be reactivated in vitro by treatment with denaturants such as SDS, guanidine $\mathrm{HCl}$, and urea [43]. It has been suggested that negatively charged phospholipids exposed on the surface of activated platelets could reactivate PAI-1 [47].
Studying the latency transition of PAI-1 the researchers showed that this process was related with the changes in tertiary structure. This transition is one of the largest structural rearrangements known for a folded protein without a concomitant change in covalent structure. It was shown that some mutations could decrease the rate of latency transition [48]. So, the methods of site-directed mutagenesis are successfully used to study PAI-1 conformation transition.

To consider the mechanism of PAI-1 stressed-to-relaxed transition we should pay attention to the peculiarities of secondary and tertiary structures of this protein. There are 9 parts of alpha-helical structures marked as hA-hI and the strands of beta-sheet structure form beta-sheets A, B, and C. As it is shown at Fig. 2 beta-sheet A contains 6 strands (s1A-s6A) and beta-sheet $\mathrm{C}$ has 4 strands (s1C-s4C). There is a flexible site between beta sheets $\mathrm{A}$ and $\mathrm{C}$. It contains 17 amino acid residues that is a site of recognition by serine proteases, so called central reactive loop (CRL). In the structure of CRL there is a special site $\mathrm{P}_{1}-\mathrm{P}^{\prime}{ }_{1}$, which is attacked by proteases. In case of PAI-1 this is a peptide bond Arg 369-Met 370 [49].

During S-R transition the N-terminal part of CRL inserts into beta-sheet $\mathrm{A}$ as $\mathrm{s} 4 \mathrm{~A}$ (see Fig.2, black arrow), and its $\mathrm{C}$-terminal extension, forming $\mathrm{s} 1 \mathrm{C}$ in the active conformer, stretched out along the surface of the molecule. As the $\mathrm{P}_{1}-\mathrm{P}_{1}{ }^{\prime}$ is not cleaved during latency transition, the intact CRL must be stretched out and completely extracted from beta-sheet $\mathrm{A}$ and pass a narrow gate region between $\mathrm{s} 3 \mathrm{C}$ and $\mathrm{s} 4 \mathrm{C}$. As a result s4A can be completed [50]. The rate of S-R for PAI-1 was suggested to be limited by the rate of CRL passage through the above mentioned gate region. This suggestion is in concordance with the data, obtained when basic amino acid residues in the loop s3C/s4C were substituted with acidic ones. Such substitution leads to the acceleration of latency transition [51]. Amino acid residues in the $\mathrm{s} 1 \mathrm{C}$ region are also very important for the PAI-1transition into latent state. It was shown that mutations, which led to weakness of interactions in this region, facilitated the conformational transition to the latent state and affected the overall structural stability of PAI-1 [52].

The presence of halide ions makes essential influence on latency transition. Crystallografic 


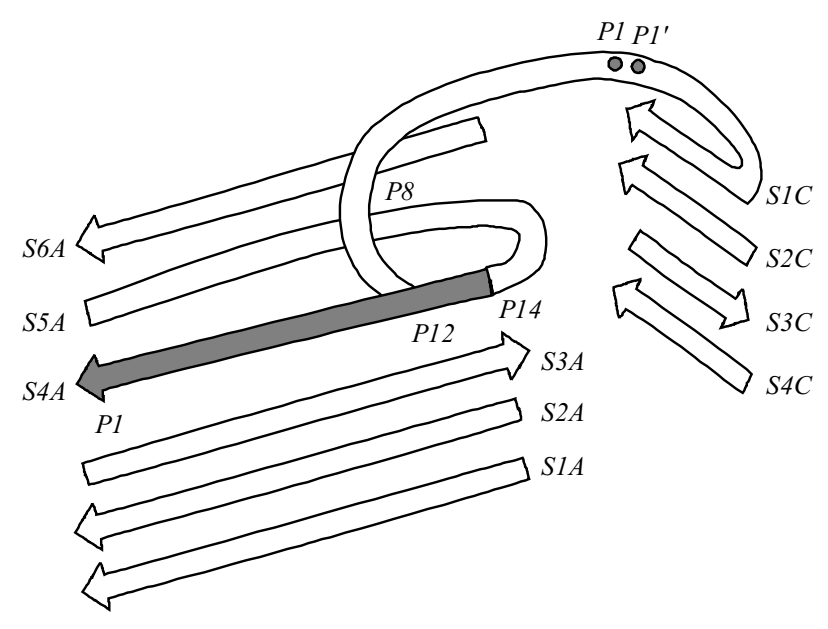

Fig. 2. Schematic beta-sheets A and C in serpin structure [49].

analysis of a stable mutant form of active PAI-1 identified an anion-binding site between the central beta-sheet, where CRL was inserted, and the small surface domain. The anion insertion stabilized the active form of PAI-1. The stabilization induced by halide-anion was decreased in a row: $\mathrm{F}^{-}>\mathrm{Cl}^{-}>\mathrm{Br}^{-}>>\mathrm{I}^{-}[53]$.

The binding of vitronectin to PAI-1 also influences the S-R transition. Half-life of the PAI-1 active form significantly increases in the presence of vitronectin $[13,28]$. Some authors suggested that vitronectin induced conformational changes in CRL [54, 55]. Later, studying a three-dimensional structure of PAI-1-somatomedin B complex, the researchers made a conclusion that vitronectin sterically impedes the transition of s2A and s3A towards hE helical structure. So, the opening of beta-sheet A, which is important for $\mathrm{CRL}$ insertion, can be delayed. It is known that CRL insertion as S4A strand, which takes place during the PAI-1 latency transition, is accompanied with the transition of s1 A, s2A, s3A, hF and the linking region binding $\mathrm{hF}$ and $\mathrm{s} 3 \mathrm{~A}$. There are also some changes in the flexible linking region, which is close to the helical structures $\mathrm{hE}$ and $\mathrm{hD}$. However, the data, obtained with the substitution of Lys 346 in s5A strand, suggested more complicated mechanism of vitronectin participation. It was shown that changing this lysine residue with alanine in PAI-1 structure in the absence of vitronectin delayed latency transition meanwhile in the presence of vitronectin such substitution led to the acceleration of this process [57]. It is obvious that vitronectin not only makes sterical effect but also leads to the conformational changes in PAI-1 structure. It is in concordance with the data of Sui G. S. et al [58]. They showed that significant acceleration of latency transition induced by point mutation in $\mathrm{s} 1 \mathrm{~A}$ and $\mathrm{hF}$ in PAI-1 protein was not observed in the presence of vitronectin.

There is another proposed mechanism concerning the PAI-1 transition into latent state and the role of vitronectin during this process [59]. According to the proposed model, there are some conformation states of PAI-1 (I-IV), which are determined by reciprocal location of s3A and s5A in A-sheet. State I: s3A and s5A are situated close to each other along their whole length. In this state CRL can not be inserted into sheet A. State II: s3A and s5A widen out near CRL, so the loop can be inserted into sheet $\mathrm{A}$ for a short distance. State III: CRL is inserted into sheet A till the P11 residue. State IV (latent state): CRL is completely inserted into sheet A. This state is practically irreversible under physiological conditions. The authors of this work suppose that in the presence of vitronectin the equilibrium between states II and III is shifted towards state II. As a result the latency transition of PAI-1 can be delayed.

Inhibitory mechanism of PAI-1. The inhibitory mechansm of PAI-1 was described in the literature, however, some details of this mechanism were not clarified [60]. Using modern biophysical and biochemical methods e.g. X-ray analysis, the main steps of the inhibition have been studied. The postulated mechanism suggests the following: 1) formation of a reversible Michaelis complex, where $\mathrm{P}_{1}-\mathrm{P}_{1}{ }^{\prime}$ bond in CRL docks into the active site of serine protease; 2) splitting peptide bond $\mathrm{P}_{1}-\mathrm{P}_{1}{ }^{\prime}$ and formation of an acyl-enzyme intermediate, in which the serine in active site of the protease is attached to the carbonyl group of Arg residue, which is located at P1 of the serpin molecule; 3 ) insertion of the $\mathrm{N}$-terminal side of CRL into beta-sheet A, due to that the dragging of the protease to the other pole of serpin takes place; 4) deformation of the protease active site, preventing completion of the catalytic cycle $[9,61,62]$. UPA and TPA attack peptide bond Arg 369-Met 370 in PAI-1 molecule [63-66]. The substitution of these residues by the method of site-directed mutagenesis showed the importance of this peptide bond for the active centre of 
TPA molecule. After splitting this bond, Arg 369 of PAI-1 and serine of the protease active centre form the ester bond. The existence of such bond was proved by direct methods of the protein chemistry [67]. In PAI-1 molecule amino acid residues Glu 373 and Glu 374 are very important for this reaction. They are complementary to the certain sites in 37-th loop of UPA and TPA, Arg 179-Arg 182 and Lys 296-Arg 304, correspondingly $[68,69]$. The second order rate constants for the inhibition reaction are $10^{7} \mathrm{M}^{-1} \mathrm{c}^{-1}$ and $10^{6} \mathrm{M}^{-1} \mathrm{c}^{-1}$ for TPA and UPA, respectively [70].

Depending on the conditions, some stages of PAI-1 inhibition reaction are probably reversible. So, the covalent complex PAI-1-TPA (M.m. 110kDa), which is rather stable under physiological conditions, can be accomplished with $\mathrm{NH}_{4} \mathrm{OH}$ [71] or SDS [72]. In circulating plasma PAI-1 can be present in three states: active state in a complex with vitronectin, inactive state as a complex PAI-1-vitronectin-TPA and free state [73-75]. The last one is also called split form. According to the proposed mechanism there are two alternative pathways of the protease-serpin reaction. The covalent acyl-enzyme intermediate can go either of two paths: 1) leading to the stable serpin-protease complex formation or 2) disintegration of intermediate complex with the formation of reactive centre-cleaved serpin and active protease. The equilibrium of these processes depends on temperature, ionic strength, detergents [76-78].

Under physiological conditions the PAI-1-protease complex can probably circulate in plasma till the moment when it is bound to the low density lipoprotein receptor 1B (LRP1B) of hepatocytes. After binding with this receptor, the complex PAI-1-TPA enters into the cell by phagocytosis and degrades under action of intracellular proteases [79].

Being the inhibitor of serine proteases, PAI-1 is able to inhibit not only TPA and UPA, but also the activated protein $\mathrm{C}$ and thrombin, however, for these proteins there are specific inhibitors in plasma (protein $\mathrm{C}$ inhibitor and antithrombin III). It is thought that the activated protein $\mathrm{C}$ binding with PAI-1shows its pro-fibrinolytic activity. The second rate constant for the activated protein $\mathrm{C}$ inhibition by PAI-1 is $10^{3} \mathrm{M}^{-1}$ $\mathrm{c}^{-1}[80,81]$ In the presence of vitronectin this value was $1.8 \times 10^{5} \mathrm{M}^{-1} \mathrm{c}^{-1}[82]$. Noteworthy that under similar conditions the rate of the reaction between PAI-1 and TPA was 100 times higher, so protein $\mathrm{C}$ can affect the TPA activation only being in concentration excess [70, 82]. The activated protein $C$ forms stable complexes with PAI-1 which can be eliminated from plasma by endothelial cells [43].

PAI-1 as a modulator of cell adhesion in tumor cells. Plasminogen, PAI-1, urokinase, and its specific receptor UPAR take part in the mitogenic, chemotactic, adhesive and migratory processes in cells. These components of fibrinolytic system play an important role in the neovascularization and tumor development [83]. It was shown that tumor tissues express urokinase and UPAR because these molecules provide tumor cells with proteolytic activity, which is a precondition for invasion [84, 85].

UPAR consists of three structural domains: D1, D2 and D3. The N-terminal domain, which is called D1, has a sequence responsible for urokinase binding, whereas D2 is needed for interaction with vitronectin [85]. In vitronectin molecule the SMB domain contains site for UPAR binding [85]. Urokinase binding with its specific receptor increases the UPAR affinity towards vitronectin and leads to the formation of stable complex between UPAR and some integrins (e.g. $\beta 1$ and $\beta 3$ integrins) [86], and induces activation of signal molecules, which are essential for the cell migration $[84,85]$.

It was found that the increase in urokinase level was accompanied by the elevation of PAI-1 concentration in plasma. That effect was observed for many types of tumor. Some authors showed that PAI-1 prevented cellular adhesion mediated by integrins and UPAR [84, 85, 87]. The adhesion inhibition by PAI-1 was observed for U937 cells (adhesion is provided by UPAR binding with vitronectin), MCF7 cells (make adhesive contact with vitronectin through integrins), HT1080 and HeLa (they use both adhesive receptors) [85]. The binding sites for PAI-1, UPAR and integrins are closely situated at the N-terminal part of vitronectin molecule. So PAI-1 can be considered as a possible competitor inhibitor in the interaction of UPAR or integrins with vitronectin $[36,85]$. It was shown that the inhibition of adhesive process depends on the binding of the inhibitor to the SMB domain of vitronectin [88]. As a result PAI-1 is able to be in the 


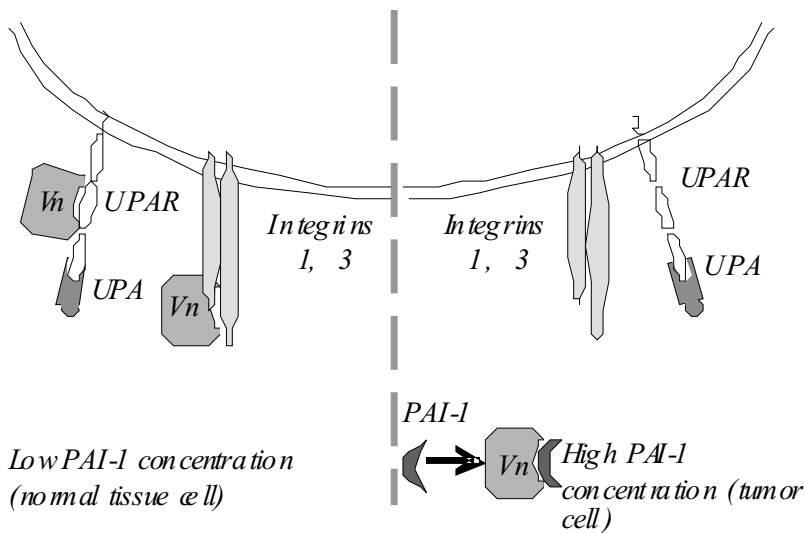

Fig. 3. Schematic possible influence of PAI-1 on cell adhesion process. UPA-urokinase, UPAR-urokinase receptor, $\mathrm{Vn}$-vitronectin.

way of adhesive contacts, which are mediated by integrins, thus promoting cell migration (see. Fig.3). Besides, the components of fibrinolytic system take part in the neovascularization process of tumor cells. Urokinase and plasmin can contribute to angiogenesis by degrading the components of extracellular matrix and taking part into migration of endothelial cells. At the same time proteolysis induced by plasmin is controlled by physiological inhibitors such as PAI-1 to stabilize matrix and to group endotheliocytes during the vessel formation [85]. Angiogenic effect of PAI-1 depends on its concentration, tumor type and stage. PAI-1 deficiency has no effect on sarcoma development, melanoma metastasis, primary tumor growth and tumor extension in the model of adenocarcinoma of mammary glands [2]. PAI-1 deficiency prevents tumor invasion and vascularization. However, invasion and angiogenesis are restored if PAI-1deficiency compensated and expression renewed. So, PAI-1 can contribute to the invasion and vascularization of tumor cells [88]. Recent researches have shown that a role of PAI-1 in cell migration is ambiguous and depends on its interaction with vitronectin. If PAI-1 forms a complex with vitronectin, the signaling and cell migration are suppressed [89]. These data are in accordance with the fact that PAI-1 prevents cell migration, which is induced by UPAR [90]. On the other hand, as it was mentioned above, PAI-1 competes for vitronectin binding site on the cellular surface, impedes cellular adhesion, which is mediated by integrins, and promotes cell migration. Apparently, the cell migration process depends not only on PAI-1 concentration but also on the type of its active form (vitronectin-bound or non-bound).

Perspectives of PAI-1 investigations. The inhibitors of serine proteases are very attractive for investigators because of their wide spread occurrence in nature. They are found in all living systems except bacteria [9]. In general, serpins control proteolytic degradation, but, as it was shown in case of PAI-1, their biological functions can be more complicated. One of the promising approaches to the serpin usage is the synthesis of compounds which possess the same efficiency as the natural inhibitors, but have their CRLs in constantly active state. These compounds could be used to inactivate the proteases of pathogenic microorganisms.

If the amount or activity of PAI-1 could be regulated we would be able to control the cellular adhesive properties and mobility which has a great importance for therapy [83]. Some authors consider PAI-1 as a potential target in tumor diseases [54, 55], therefore, the screening of agents inactivating PAI-1 is an important part of the modern investigations. Some peptides or monoclonal antibodies may be possible candidates. These agents of directed action have to be tested first on animal models, and in future they could be a base for creating medical preparations.

\section{Д. Д. Жерносеков, Э. Н. Золотарева, А. С. Кондратюк}

Структурно-функциональные особенности ингибитора активатора плазминогена ПАИ-1

Резюме

ПАИ-1,важный компонент системы гемостаза, является спеичфическим ингибитором активаторов плазминогена тканевого (ТПА) и урокиназного (УПА) типов. ПАИ-1 относится к семейству серпинов. Взаимодействие с соматомединоподобным доменом витронектина стабилизирует ак- тивную форму ингибитора. Переход ПАИ-1 в латентное состояние сопряжен с конформационными изменениями в области петли реактивного иентра. Механизм ингибиторного действия ПАИ-1 соответствует классической схеме ингибирования серпинами. ПАИ-1 блокирует адгезию, опосредованную реиептором УПА и интегринами, выполняя при этом важную роль в адгезивных процессах и ангиогенезе. Изменения уровня ПАИ-1 рассматривают как важный прогностический признак при заболеваниях 
сердечно-сосудистой системы (инфаркт миокарда, инсульт), фиброзе почек, диабете, каниерогенезе.

Ключевые слова: ПАИ-1, фибринолиз, миграџия клеток.

\section{Д. Д. Жерносєков, Е. М. Золотарьова, А. С. Кондратюк}

Структурно-функціональні особливості інгібітора активатора плазміногену ПАІ-1

Резюме

ПАI-1, важливий компонент системи гемостазу, є специфічним інгібітором активаторів плазміногену тканинного (ТПА) та урокіназного типів. ПАІ-1 належить до серпінової родини. Взаємодія з соматоподібним доменом вітронектину стабілізує активну форму інгібітора. Перехід ПАI-1 до латентного стану пов'язаний з конформаційними змінами у ділянці петлі реактивного центра. Механізм інгібіторної дії ПАI-1 відповідає класичній схемі серпінового інгібування. ПАІ-1 блокує адгезію опосередковану рецептором УПА та інтегринами, виконуючи при иьому важливу роль в адгезивних процессах та ангіогенезі. Зміни рівня ПАІ-1 розглядають як істотну прогностичну ознаку при захворюваннях серцево-судинної системи, фіброзі нирок, діабеті, канцерогенезі.

Ключові слова: ПАI-1, фібриноліз, міграція клітин.

\section{REFERENCES}

1. Ha H., Oh E. Y., Lee H. B. The role of plasminogen activator inhibitor-1 in renal and cardiovascular diseases // Nat. Rev. Nephrol.-2009.-5, N 4.-P. 203-211.

2. Diebold I., Kraicum D., Bonsello S., Gorlach A. The «PAI-1 paradox» in vascular remodeling // Thromb. Haemost.2008.-100, N 6.-P. 984-991.

3. Ma L. J., Fogo A. B. Plasminogen activator inhibitor-1 and kidney fibrosis // Front Biosci.-2009.-1, N 14.-P. 2028-2041.

4. Matsuzawa $Y$. The role of fat topology in the risk of disease // Int. J. Obes. (Lond).-2008.-32, N 7.-P. 83-89

5. Juhan-Vague I., Alessi M. C., Morange P. E. Hypofibrinolysis and increased plasminogen activator inhibitor-1 are linked to atherothrombosis via insulin resistance and obesity // Ann. Med.-2000.-32, N 1.-P. 78-84.

6. Binder B. R., Christ G., Gruber F., Grubic N., Hufnagl P., Krebs M., Mihaly J., Pager G. W. Plasminogen activator inhibitor-1: physiological and pathophysiological roles // News Physiol. Sci.-2002.-17.-P. 56-61.

7. Mc Mahon B., Kwaan H. C. The plasminogen activator system and cancer// Pathophys. Haemost. Tromb.-2008.-36, N 3-4.-P. 184-194.

8. Ulisse S., Baldini E., Sorrenti S., D'Armiento M. The urokinase plasminogen activator system: a target for anticancer therapy // Curr. Cancer Drug Targets.-2009.-9, N 1.-P. 3271.

9. Dupont D. M., Madsen J. B., Kristensen T., Bodker J. S., Blou se G. E., Wind T., Andreasen P. A. Biochemical properties of plasminogen activator inhibitor-1 // Front. Biosci.-2009.14.-P. 1337-1361.

10. Volkov G. L., Platonova T. N., Savchuk A. N., Gornitskaya O. V., Chernyshenko T. M., Krasnobryzhaya E. N. Modern conceptions of hemostasis system.-Kyiv: Naukova Dumka, 2005.-296 p.

11. Zubairov D. M. Molecular basis of coagulation and thromb formation.-Kazan: FEN, 2000.-364 p.

12. Declerck P. J., De Mol M., Alessi M. C., Baudner S., Paques E. P., Preissner K. T., Muller-Berghaus G., Collen D. Purification and characterization of a plasminogen activator inhibitor 1 binding protein from human plasma. Identification as a multimeric form of S protein (vitronectin) // J. Biol. Chem.1988.-263, N 30.-P. 15454-15461.

13. Wiman B., Almquist A., Sigurdadottir O., Lindahl T. Plasminogen activator inhibitor 1 (PAI) is bound to vitronectin in plasma // FEBS Lett.-1988.-242, N 1.-P. 125-128.

14. Booth N. A., Robbie L. A., Croll A. M., Bennett B. Lysis of platelet-rich thrombi: the role of PAI-1 // Ann. Nat. New York Acad. Sci.-1992.-667.-P. 70-80.

15. Robbie L. A., Bennett B., Croll A. M., Brown P. A., Booth N. $A$. Proteins of the fibrinolytic system in human thrombi // Thromb. Haemost.-1996.-75, N 1.-P. 127-133.

16. Dellas C., Loskutoff D. J. Historical analysis of PAI-1 from its discovery to its potential role in cell motility and disease // Thromb. Haemost.-2005.-93, N 4.-P. 631-640.

17. Klinger K. W., Winqvist R., Riccio A., Andreasen P. A., Sartorio R., Nielsen L. S., Stuart N., Stanislovitis P., Watkins P., Douglas $R$. Plasminogen activator inhibitor type 1 gene is located at region q21.3-q22 of chromosome 7 and genetically linked with cystic fibrosis // Proc. Nat. Acad. Sci. USA.1987.-84, N 23.-P. 8548-8552.

18. Cicila G. T., O'Connell T. M., Hahn W. C., Rheinwald J. G. Cloned cDNA sequence for the human mesothelial protein «mesosecrin» discloses its identity as a plasminogen activator inhibitor (PAI-1) and a recent evolutionary change in transcript processing // J. Cell Sci.-1989.-94, N 1.-P. 1-10.

19. Brogren H., Karlsson L., Andersson M., Wang L., Erlinge D., Jern $S$. Platelets synthesize large amounts of active plasminogen activator inhibitor $1 / /$ Blood.-2004.-104, N 13.P. 3943-3948.

20. Andreasen P. A., Georg B., Lund L. R., Riccio A., Stacey S. N. Plasminogen activator inhibitors: hormonally regulated serpins // Mol. Cell. Endocrinol.-1990.-68, N 1.-P. 1-19.

21. De Taeye B., Smith L. H., Vaughan D. E. Plasminogen activator inhibitor-1: a common denominator in obesity, diabetes and cardiovascular disease // Curr. Opin. Pharmacol.-2005.5.-P. 149-215.

22. Seifert S. C., Gelehrter T. D. Mechanism of dexamethasone inhibition of plasminogen activator in rat hepatoma cells // Proc. Nat. Acad. Sci. USA.-1978.-75, N 12.-P. 6130-6133.

23. Andersen P. A., Riccio A., Welinder K. G., Douglas R., Sartorio R., Nielsen L. S., Oppenheimer C., Blasi F., Dano K. Plasminogen activator inhibitor type-1 reactive center and amino-terminal heterogeneity determined by protein and cDNA sequencing // FEBS Lett.-1986.-209, N 2.-P. 213218.

24. Rheiwald J. G., Jorgensen J. L., Hahn W. C., Terpstra A. J., $O$ 'Connell T. M., Plummer K. K. Mesosecrin: a secreted glycoprotein produced in abundance by human mesothelial, endothelial, and kidney epithelial cells in culture // J. Cell. Biol.-1987.-104, N 2.-P. 263-275. 
25. Gils A., Pedersen F., Skottrup P., Christensen A., Naessens D., Deinum J., Enghild J. J., Declerck P. J., Andreasen P. A. Biochemical importance of glycosylation of plasminogen activator inhibitor-1 // Thromb. Haemost.-2003.-90, N 2.P. 206-217.

26. Brogren H., Sihlbom C., Wallmark K., Lonn M., Deinum J., Karlsson L., Jern S. Heterogeneous glycosylation patterns of human PAI-1 may reveal its cellular origin // Thromb. Res.2008.-122, N 2.-P. 271-278.

27. Serrano R., Barrenetxe J., Orbe J., Rodriguez J. A., Gallardo N., Martinez C., Andres A., Paramo J. A. Tissue-specific PAI-1 gene expression and glycosylation pattern in insulinresistant old rats // Am. J. Physiol. Regul. Integr. Comp. Physiol.-2009.-297, N 5.-P. R1563-R1569.

28. Mimuro J., Loskutoff D. J. Purification of a protein from bovine plasma that binds to type 1 plasminogen activator inhibitor and prevents its interaction with extracellular matrix. Evidence that the protein is vitronectin // J. Biol. Chem.1989.-264, N 2.-P. 936-939.

29. Preissner K. T., Seiffert D. Role of vitronectin and its receptors in haemostasis and vascular remodeling // Thromb. Res.1998.-89, N 1.-P. 1-21.

30. Preissner K. T., Holzhuter S., Justus C., Muller-Berghaus G. Identification of and partial characterization of platelet vitronectin: evidence for complex formation with platelet-derived plasminogen activator inhibitor-1 // Blood.-1989.-74, N 6.P. 1989-1996.

31. Lang I. M., Schleef R. R. Calcium-dependent stabilization of type I plasminogen activator inhibitor within platelet alphagranules // J. Biol. Chem.-1996.-271, N 5.-P. 2754-2761.

32. Seiffert $D$., Schleef $R$. R. Two functionally distinct pools of vitronectin $(\mathrm{Vn})$ in the blood circulation: identification of a heparin-binding competent population of $\mathrm{Vn}$ within platelet alpha-granules // Blood.-1996.-88, N 2.-P. 552-560.

33. Parker C. J., Stone O. L., White V. F., Bernshaw N. J. Vitronectin (S protein) is associated with platelets // Br. J. Haematol.-1989.-71, N 2.-P. 245-252.

34. Podor T. J, Singh D., Chindemi P., Foulon D. M., McKelvie R., Weitz J. I., Austin R., Boudreau G., Davies R. Vimentin exposed on activated platelets and platelet microparticles localizes vitronectin and plasminogen activator inhibitor complexes on their surface // J. Biol. Chem.-2002.-277, N 9.P. 7529-7539.

35. Lawrence D. A., Berkenpas M. B., Palaniappan S., Ginsburg $D$. Localization of vitronectin binding domain in plasminogen activator inhibitor-1 // J. Biol. Chem.-1994.-269, N 21.P. 15223-15228.

36. De Prada N. A., Schroeck F., Sinner E. K., Muehlenweg B., Twellmeyer J., Sperl S., Wilhelm O. G., Schmitt M., Magdolen $V$. Interaction of plasminogen activator inhibitor type-1 (PAI1) with vitronectin // Eur. J. Biochem.-2002.-269, N 1.P. 184-192.

37. Mayasundari A., Whittemore N. A., Serpersu E. H., Peterson $C$. $B$. The solution structure of the N-terminal domain of human vitronectin // J. Biol. Chem.-2004.-279, N 28.P. 29359-29366.

38. Sigurdardottir $O$., Wiman B. Complex formation between plasminogen activator inhibitor 1 and vitronectin in purified systems and in plasma // Biochim. Biophys. Acta.-1990.1035, N 1.-P. 56-61.

39. Seiffert D., Loskutoff D. J. Evidence that type 1 plasminogen activator inhibitor binds to the somatomedin B domain of vitronectin // J. Biol. Chem.-1991.-266, N 5.-P. 2824-2830.

40. Okumura Y., Kamikubo Y., Curriden S. A., Wang J., Kiwada T., Futaki S., Kitagawa K., Loskutoff D. J. Kinetic analysis of the interaction between vitronectin and the urokinase receptor // J. Biol. Chem.-2002.-277, N 11.-P. 9395-9404.

41. Stefansson S., Lawrence D. A. The serpin PAI-1 inhibits cell migration by blocking integrin alpha $\mathrm{V}$ beta 3 binding to vitronectin // Nature.-1996.-383, N 6599.-P. 441-443.

42. Sancho E., Declerck P. J., Price N. C., Kelly S. M., Booth N. $A$. Conformational studies on plasminogen activator inhibitor (PAI-1) in active, latent, substrate, and cleaved forms // Biochemistry.-1995.-34, N 3.-P. 1064-1069.

43. Hekman C. M., Loskutoff D. J. Endothelial cells produce a latent inhibitor of plasminogen activators that can be activated by denaturants // J. Biol. Chem.-1985.-260, N 21.-P. 1158111587.

44. Levin E. G., Santell L. Conversion of the active to latent plasminogen activator inhibitor from human endothelial cells // Blood.-1987.-70, N 4.-P. 1090-1098.

45. Loskutoff D. J., Sawdey M., Mimuro J. Type 1 plasminogen activator inhibitor // Prog. Hemost. Thromb.-1989.-9.P. 87-115.

46. Lawrence A., Palaniappan S., Stefansson S., Olson S. T., Francis-Chmura A. M., Shore J. D., Ginsburg D. Characterization of the binding of different conformational forms of plasminogen activator inhibitor-1 to vitronectin. Implications for the regulation of pericellular proteolysis // J. Biol. Chem.1997.-272, N 12.-P. 7676-7680.

47. Lambers J. W., Cammenga M., Konig B. W., Mertens K., Pannekoek H., van MourikJ. A. Activation of human endothelial cell-type plasminogen activator inhibitor (PAI-1) by negatively charged phospholipids // J. Biol. Chem.-1987.-262, N 36.-P. 17492-17496.

48. Stoop A. A., Eldering E., Dafforn T. R., Read R. J., Pannekoek $H$. Different structural requirements for plasminogen activator inhibitor 1 during latency transition and proteinase inhibition as evidenced by phage-displayed hypermutated PAI-1 libraries // J. Mol. Biol.-2001.-305, N 4.-P. 773- 783.

49. Bode $W$., Huber R. Proteinase-protein inhibitor interactions // Fibrinolysis.-1994.-8, N 1.-P. 161-171.

50. Kruger P., Verheyden S., Declerck P. J., Engelborghs Y. Extending the capabilities of targeted molecular dynamics: simulation of a large conformational transition in plasminogen activator inhibitor $1 / /$ Protein Sci.-2001.-10, N 4.-P. 798808.

51. Gils A., Lu J., Aertgeerts K., Knockaert I., Declerck P. J. Identification of positively charged residues contributing to the stability of plasminogen activator inhibitor $1 / /$ FEBS Lett.-1997.-415, N 2.-P. 192-195.

52. Na Y. R., Im H. Specific interactions of serpins in their native forms attenuate their conformational transitions // Protein Sci.-2007.-16, N 8.-P. 1659-1666.

53. Stout T. J., Graham H., Buckley D. I., Matthews D. J. Structures of active and latent PAI-1: a possible stabilizing role for chloride ions // Biochemistry.-2000.-39, N 29.-P. 84608469 .

54. Fa M., Karolin J., Aleshkov S., Strandberg L., Johansson L. $B$., $N y$ T. Time-resolved polarized fluorescence spectroscopy studies of plasminogen activator inhibitor type 1 : conformational changes of the reactive center upon interactions with target proteases, vitronectin and heparin // Biochemistry.-1995.-34, N 42.-P. 13833-13840.

55. Gibson A., Baburaj K., Day D. E., Verhamme I., Shore J. D., Peterson C. B. The use of fluorescent probes to characterize conformational changes in the interaction between vitronectin and plasminogen activator inhibitor-1// J. Biol. Chem.1997.-272, N 8.-P. 5112-5121.

56. Zhou A., Huntington J. A., Pannu N. S., Carrell R. W., Read $R$. $J$. How vitronectin binds PAI-1 to modulate fibrinolysis 
and cell migration // Nat. Struct. Biol.-2003.-10, N 7.P. 541-544.

57. Hansen M., Busse M. N., Andreasen P. A. Importance of the amino-acid composition of the shutter region of plasminogen activator inhibitor-1 for its transition to latent and substrate forms // Eur. J. Biochem.-2001.-268, N 23.-P. 6274-6283.

58. Sui G. S., Wiman B. Stability of plasminogen activator inhibitor-1: role of tyrosine $221 / /$ FEBS Lett.-1998.-423, N 3.P. 319-323.

59. Li S-H., Gorlatova N. V., Lawrence D. A., Schwartz B. S. Structural differences between active forms of plasminogen activator inhibitor type 1 revealed by conformationally sensitive ligands // J. Biol. Chem.-2008.-283, N 26.-P. 1814718157.

60. Silverman G. A., Bird P. I., Carrell R. W., Church F. C., Couglin P. B., Gettins P. G. W., Irving J. A., Ljmas D. A., Luke C. J., Moyer R. W., Pemberton P. A., Remold-O'donnell E., Salversen $G$. S., Travis J., Whisstock J. C. The serpins are an expanding superfamily of structurally similar but functionally diverse proteins // J. Biol. Chem.-2001.-276, N 36P. 33293-33296.

61. Ye S., E. J. Goldsmith E. J. Serpins and other covalent protease inhibitors // Curr. Opin. Struct. Biol.-2001.-11, N 6.P. 740-745.

62. Wind T., Hansen M., Jensen J. K., Andreasen P. A. The molecular basis for anti-proteolytic and non-proteolytic functions of plasminogen activator inhibitor type-1: roles of the reactive centre loop, the shutter region, the flexible joint region and the small serpin fragment // J. Biol. Chem.-2002.-383, N 1.-P. 21-36.

63. Lawrence D. A., Strandberg L., Ericson J., Ny T. Structurefunction studies of the SERPIN plasminogen activator inhibitor type 1. Analysis of chimeric strained loop mutants // J. Biol. Chem.-1990.-265, N 33.-P. 20293-20301.

64. Sherman P. M., Lawrence D. A., Yang A. Y., Vandenberg E. T., Paielli D., Olson S. T., Shore J. D., Ginsburg D. Saturation mutagenesis of the plasminogen activator inhibitor-1 reactive center // J. Biol. Chem.-1992.-267, N 11.-P. 75887595.

65. Sherman P. M., Lawrence D. A., Paielli V. D., Shore J. D., Ginsburg $D$. Identification of tissue-type plasminogen activator-specific plasminogen activator inhibitor-1 mutants. Evidence that second sites of interaction contribute to target specificity // J. Biol. Chem.-1995.-270, N 16.-P. 93019306.

66. York J. D., Li P., Gardell S. J. Combinatorial mutagenesis of the reactive site region in plasminogen activator inhibitor I // J. Biol. Chem.-1991.-266, N 16.-P. 8495-8500.

67. Egelund R., Rodenburg K. W., Andreasen P. A., Rasmussen M. S., Guldberg R. E., Petersen T. E. An ester bond linking a fragment of a serine proteinase to its serpin inhibitor // Biochemistry.-1998.-37, N 18.-P. 6375-6379.

68. Ibarra C. A., Blouse G. E., Christian T. D., Shore J. D. The contribution of the exosite residues of plasminogen activator inhibitor-1 to proteinase inhibition // J. Biol. Chem.-2004.279, N 5.-P. 3643-3650.

69. Tucker H. M., Gerard R. D. Sequence requirements in the reactive-center loop of plasminogen-activator inhibitor-1 for recognition of plasminogen activators // Eur. J. Biochem.-1996.-237, N 1.-P. 180-187.

70. Krisnamurti Ch., Alving B. Plasminogen activator inhibitor type 1: biochemistry and evidence for modulation of fibrinolysis in vivo // Semin. Thromb. and Hemost.-1992.-18, N 1.P. 67-80.

71. Lindahl T. L., Ohlsson P. I., Wiman B. The mechanism of the reaction between human plasminogen-activator inhibitor 1 and tissue plasminogen activator // Biochem. J.-1990.-265, N 1.-P. 109-113.

72. Gaussem P., Grailhe P., Angles-Cano E. Sodium dodecyl sulfate-induced dissociation of complexes between human tissue plasminogen activator and its specific inhibitor // J. Biol. Chem.-1993.-268, N 16.-P. 12150-12155.

73. Stefansson S., Haudenschild C., Lawrence D. Beyond fibrinolysis: the role of plasminogen activator inhibitor and vitronectin in vascular wound healing // Trends Cardiovascul. Med.-1998.-8, N 4.-P. 175-180.

74. Debrock S., Declerck P. J. Neutralization of plasminogen activator inhibitor-1 inhibitory properties: identification of two different mechanisms // Biochim. Biophys. Acta.-1997.1337, N 2.-P. 257-266.

75. Alessi M. C., Juhan-Vague J., Declerck P. J., Collen D. Molecular forms of plasminogen activator inhibitor-1 (PAI-1) and tissue-type plasminogen activator (t-PA) in human plasma // Thromb. Res.-1991.-62, N 4.-P. 275-285.

76. Kjoller L., Martensen P. M., Sottrup-Jensen L., Justesen J., Rodenburg K. W., Andreasen P. A. Conformational changes of the reactive-centre loop and $\beta$-strand $5 \mathrm{~A}$ accompany temperature-dependent inhibitor-substrate transition of plasminogen-activator inhibitor $1 / /$ Eur. J. Biochem.-1996.-241, N 1.-P. 38-46.

77. Calugaru S. V., Swanson R., Olson S. T. The $\mathrm{pH}$ dependence of serpin-proteinase complex dissociation reveals a mechanism of complex stabilization involving inactive and active conformational states of the proteinase which are perturbable by calcium // J. Biol. Chem.-2001.-276, N 35.-P. 3244632455 .

78. Gettins $P$. $G$. The F-helix of serpins plays an essential, active role in the proteinase inhibition mechanism // FEBS Lett.2002.-523, N 1-3.-P. 2-6.

79. Liu C. X., Li Y., Obermoeller-McCormick L. M., Schwartz A. $L$., $B u G$. The putative tumor suppressor LRP1B, a novel member of the low density lipoprotein (LDL) receptor family, exhibits both overlapping and distinct properties with the LDL receptor-related protein // J. Biol. Chem.-2001.-276, N 31.-P. 28889-28896.

80. Sakata Y., Loskutoff D. J., Gladson C. L. Mechanism of protein $\mathrm{C}$ dependent clot lysis role of plasminogen activator inhibitor // Blood.-1986.-68, N 6.-P. 1218-1223.

81. Sakata Y., Curriden S., Lawrence D. Activated protein C stimulated the fibrinolytic activity // Proc. Nat. Acad. Sci. USA.-1985.-82, N 4.-P. 1121-1125.

82. Rezaie A. R. Vitronectin function as a cofactor for rapid inhibition of activated protein $\mathrm{C}$ by plasminogen activator-inhibitor-1. Implification for the mechanisms of profibrinolytic action of protein C // J. Biol. Chem.-2001.-276, N 19.P. $15567-15570$.

83. Sawaya $R$. Fibrinolysis and the central nervous system.Philadelphia: Hanley and Belfus Inc., 1990.-306 p.

84. Deng G., Curriden S. A., Wang S., Rosenberg S., LoskutoffD. $J$. Is plasminogen activator inhibitor-1 the molecular switch that governs urokinase receptor-mediated cell adhesion and release? // J. Cell Biol.-1996.-134, N 6.-P. 1563-1571.

85. Czekay R. P., Loskutoff D. J. Unexpected role of plasminogen activator inhibitor-1 in cell adhesion and detachment // Exp. Biol. Med.-2004.-229, N 11.-P. 1090-1096.

86. Noel A., Maillard C., Rocks N., Jost M., Chabottaux V., Sounni N. E., Maquoi E., Cataldo D., Foidart J. M. Membrane associated proteases and their inhibitors in tumour angiogenesis // J. Clin. Pathol.-2004.-57, N 6.-P. 577-584.

87. Bajou K., Noel A., Gerard R. D., Masson V., Brunner N., Hols-Hansen C., Skobe M., Fusening N. E., Carmeliet P., Collen D., Foidart J. M. Absence of host plasminogen activa- 
tor inhibitor-1 prevents cancer invasion and vascularisation // Nat. Med.-1998.-4, N 8.-P. 923-928.

88. Deng G., Curriden S. A., Hu G., Czekay R. P., Loskutoff D. J. Plasminogen activator inhibitor-1 regulates cell adhesion by binding to the somatomedin B domain of vitronectin // J. Cell Physiol.-2001.-198, N 1.-P. 23-33.

89. Kamikubo Y., Neels J. G., Degryse B. Vitronectin inhibits plasminogen activator inhibitor- 1 induced signaling and chemotaxis by blocking plasminogen activator inhibitor-1 bin- ding to the low-density lipoprotein receptor-related protein // Int. J. Biochem. Cell Biol.-2009.-41, N 3.-P. 578-585.

90. Degryse B., Sier C. F. M., Resnati M., Conese M., Blasi F. PAI-1 inhibits urokinase-induced chemotaxis by internalizing the urokinase receptor // FEBS Lett.-2001.-505, N 2.P. 249-254.

UDK 577.112.15

Received 26.10.10 